\title{
Intra and inter-monkey transmission of bacteria in wild black capuchins monkeys (Sapajus nigritus): a preliminary study
}

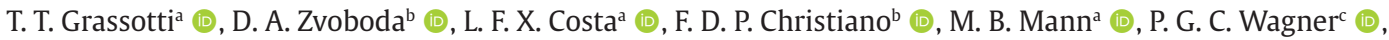 \\ A. A. S. Campos ${ }^{\mathrm{d}}$ (D) J. Frazzon ${ }^{\mathrm{e}}$ (1) and A. P. G. Frazzon ${ }^{\mathrm{a}, b^{*}}$ (1) \\ a Universidade Federal do Rio Grande do Sul - UFRGS, Programa de Pós-graduação em Microbiologia Agrícola e do Ambiente, Porto Alegre, RS, Brasil \\ ${ }^{\mathrm{b}}$ Universidade Federal do Rio Grande do Sul - UFRGS, Departamento de Microbiologia, Imunologia e Parasitologia, Porto Alegre, RS, Brasil \\ 'Instituto Brasileiro do Meio Ambiente e dos Recursos Naturais Renováveis - IBAMA, Porto Alegre, RS, Brasil \\ ¿ Secretaria da Saúde do Estado do Rio Grande do Sul, Centro Estadual de Vigilância em Saúde - CEVS, Porto Alegre, RS, Brasil \\ ' Universidade Federal do Rio Grande do Sul - UFRGS, Instituto de Ciência e Tecnologia de Alimentos, Porto Alegre, RS, Brasil
}

Black capuchin monkeys (Sapajus nigritus) are characterized by presence of robust capuchin monkeys, which have adornments or tufts on the head. Monkeys live in a social structure involves hierarchies of dominance between males and females, which results in different behaviors, such as agonistic, affiliative, and cooperative (Valença-Silva et al., 2014; Back et al., 2019). Some authors have even suggested that pro-social and affiliative behaviors (grooming, licking or kissing) might have been in part, evolved in the microbial transmission (Ezenwa et al., 2012). The gastrointestinal microbiota of primates is composed by a diverse microbial community, including Enterococcus sp (Lebreton et al., 2014). The idea of interaction between microbiota and behavior have stimulates the development of novel research to analyze the social contact and acquisition/exchange of commensal and symbiotic microbial. Thus, our aim was to investigate if there is a correlation between oral and fecal enterococci isolated from wild black capuchins monkeys.

Paired oral and rectal swabs were collected from five wild black capuchin monkeys living in a forest

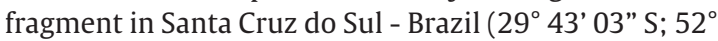
25 '33" W). Wild capuchin monkeys were captured and manipulated using conventional methods according to the protocol for sample collection described by Instituto Chico Mendes de Conservação da Biodiversidade [ICMBio] using Tomahawk-type cages. The sample collection was approved by Information Authorization System in Biodiversity number 56640 . Isolation of enterococci was performed as previously described by Santestevan et al. (2015). Collected bacteria were identified by MALDI-TOF MS and PCR amplification. Similarity between RAPD fingerprints was calculated using the simple association coefficient and cluster analysis, applying the Unweighted Pair Group Method with Arithmetic Mean (UPGMA). The strains grouping coefficients of similarity of $\geq 75 \%$ for RAPD typing were applied.
A total 114 Enterococcus spp. were isolated from paired samples, being $E$. faecalis $(\mathrm{n}=96)$ and E. casseliflavus $(\mathrm{n}=14)$ detected in both cavities, and E. hirae $(\mathrm{n}=4)$ only in one oral cavity. Using RAPD, we assessed the genetic relationships between oral and rectal strains, and the results showed an inter- or intra-transmission of enterococci among the monkeys. Clusters IV, V and XVII were composed by oral and rectal strains isolated from the same monkey, suggesting that autocoprophagy as mechanism of enterococci transmission. The clusters $\mathrm{XI}$ and XI were also formed by oral and rectal strains; however, these were isolated from different monkey suggesting that allocoprophagy as another mechanism of enterococci transmission. Two other clusters were formed by enterococci species isolated from rectal swabs from different monkey, suggesting that these bacteria might be transmitted through affiliative behavior (Figure 1). There are good evidences that gut microbial manipulate the food cravings in hosts to optimal resource for bacterial growth and induce host social interaction to facility the bacterial transmission. In addition, Schmidt et al. (2019) demonstrated the oralfecal transmission and suggested that this transmission is an important process that shapes the gastrointestinal microbiota in health and disease.

Therefore to our knowledge, this is the first study that reports the genetic relationships between oral and rectal enterococci isolated from wild black capuchin monkeys. In conclusion, despite of the fact that a low number of samples were used for comparison- justified by the difficulties to find and capture wild monkeysthis preliminary analysis suggest that coprophagy and affiliative behaviors might have an important role in shaping and maintenance of enterococci in wild monkeys. In addition, to exploring of interactions of social dynamics and microbiota in wild populations, could be an insight for future research.

*e-mail: ana.frazzon@ufrgs.br

Received: May 1, 2020 - Accepted: October 15, 2020 


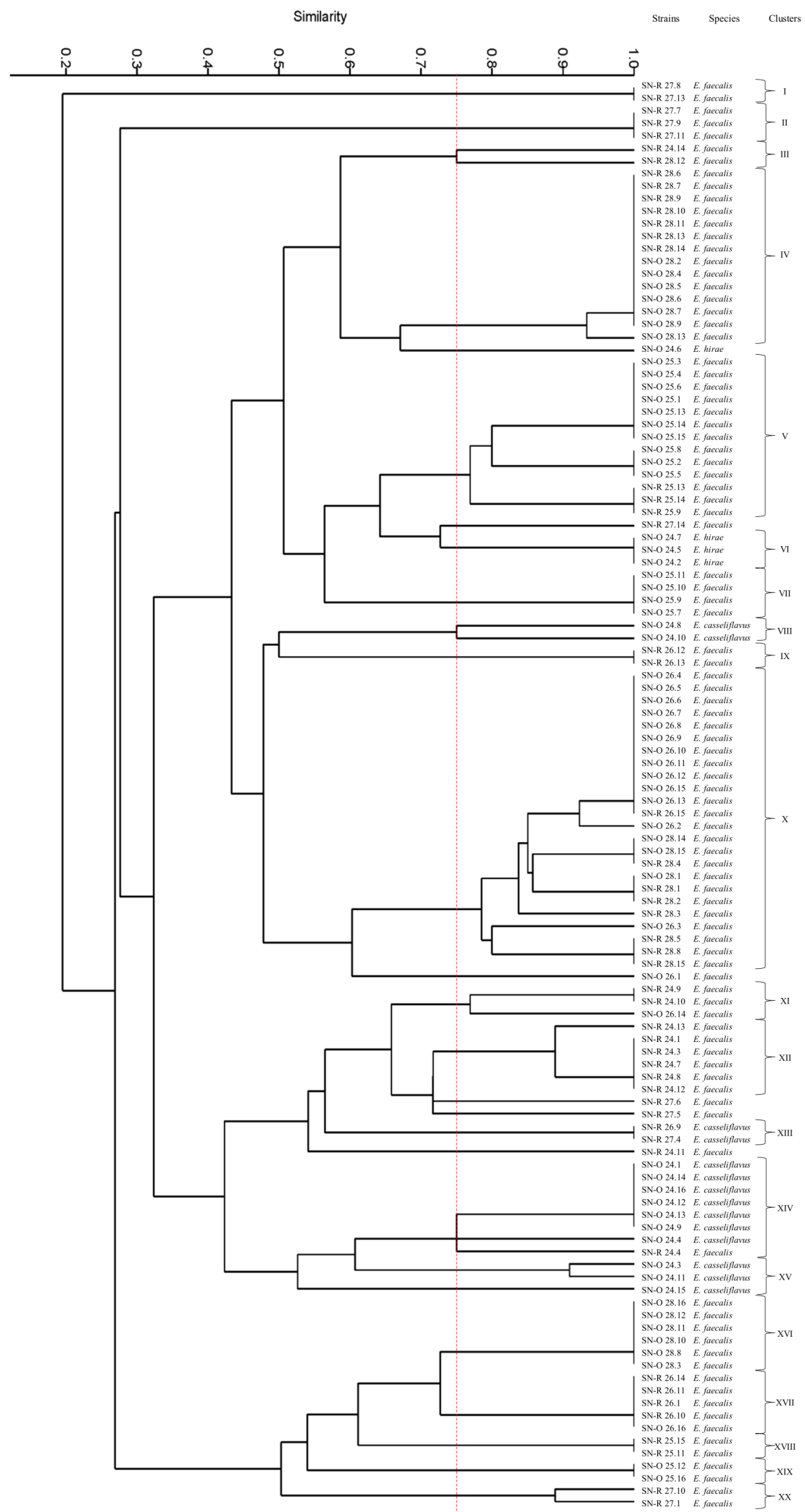

Figure 1. Unweighted Pair Group Method with Arithmetic Mean-dendrogram showing clustering pattern for 26 genotypes of enterococci isolated from paired oral $(\mathrm{O})$ and rectal $(\mathrm{R})$ swabs of black capuchin monkeys (Sapajus nigritus-SN). UPGMA using Sorensen-Dice coefficients of similarity (> 75\%). 


\section{Acknowledgements}

This work was performed within the framework of Coordenação de Aperfeiçoamento de Pessoal de Nível Superior (CAPES), a foundation linked to the Brazilian Ministry of Education that operates in the expansion and consolidation of stricto sensu graduate programs in all Brazilian states and sponsored by Conselho Nacional de Desenvolvimento Científico (CNPq - \# 407886/2018-4, and \# 302574/2017-4).

\section{References}

BACK, J.P., SUZIN, A. and AGUIAR, L.M., 2019. Activity budget and social behavior of urban capuchin monkeys, Sapajus sp. (Primates: cebidae). Zoologia, vol. 36, pp. 1-10. http://dx.doi. org/10.3897/zoologia.36.e30845.

EZENWA, V.O., GERARDO, N.M., INOUYE, D.W., MEDINA, M. and XAVIER, J.B., 2012. Animal behavior and the microbiome. Science, vol. 338, no. 6104, pp. 198-199. http://dx.doi.org/10.1126/ science.1227412. PMid:23066064.

LEBRETON, F., WILLEMS, R.J.L. and GILMORE, M.S., 2014. Enterococcus diversity, origins in nature, and gut colonization. In: M.S. GILMORE, D.B. CLEWELL, Y. IKE and N. SHANKAR, eds. Enterococci from commensals to leading causes of drug resistant infection. Boston: Massachusetts Eye and Ear Infirmary, pp. 1-52.

SANTESTEVAN, N.A., ANGELIS ZVOBODA, D., PRICHULA, J., PEREIRA, R.I., WACHHOLZ, G.R., CARDOSO, L.A., DE MOURA, T.M., MEDEIROS, A.W., AMORIN, D.B., TAVARES, M., D'AZEVEDO, P.A., FRANCO, A.C., FRAZZON, J. and FRAZZON, A.P., 2015. Antimicrobial resistance and virulence factor gene profiles of Enterococcus spp. isolates from wild Arctocephalus australis (South American fur seal) and Arctocephalus tropicalis (Subantarctic fur seal). World Journal of Microbiology \& Biotechnology, vol. 31, no. 12, pp. 1935-1946. http://dx.doi.org/10.1007/s11274-015-1938-7. PMid:26347323.

SCHMIDT, T.S., HAYWARD, M.R., COELHO, L.P., LI, S.S., COSTEA, P.I., VOIGT, A.Y., WIRBEL, J., MAISTRENKO, O.M., ALVES, R.J., BERGSTEN, E., DE BEAUFORT, C., SOBHANI, I., HEINTZ-BUSCHART, A., SUNAGAWA, S., ZELLER, G., WILMES, P. and BORK, P., 2019. Extensive transmission of microbes along the gastrointestinal tract. eLife, vol. 8, no. e42693, pp. 1-18. http://dx.doi.org/10.7554/ eLife.42693. PMid:30747106.

VALENÇA-SILVA, G., MACIEL, F.G., ZAGANINI, R.L., LUCINDO, A.S., CARAMASCHI, S. and PAULA, H.M.G., 2014. Reporting social behaviours of mixed-species troops formed by Callithrix jacchus and Callithrix penicillata (Primate, Callitrichidae). Brazilian Journal of Biology = Revista Brasileira de Biologia, vol. 74, no. 3, pp. 607611. http://dx.doi.org/10.1590/bjb.2014.0091. PMid:25296209. 